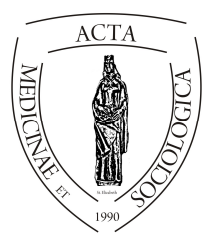

Acta Medicinae et

Sociologica (2019)

Vol. 10. No. 28.

DEBRECEN

FACULTY OF

HEALTH

doi:

\title{
Autizmusban érintett tanulók körében alkalmazható anti-bullying megközelítés egy szakirodalmi áttekintés tükrében
}

\author{
Marjai Kamilla \\ addiktológiai konzultáns, Nyírő Gyula Országos Pszichiátriai és Addiktológiai Intézet, / külső óraadó, Eötvös \\ Loránd Tudományegyetem Bárczi Gusztáv Gyógypedagógiai Kar.
}

\section{INFO ABSTRACT}

\begin{tabular}{l}
\hline $\begin{array}{l}\text { Marjai Kamilla } \\
\text { marjaikamilla@gmail.com }\end{array}$ \\
\hline Keywords \\
anti-bullying programs, \\
autism, victimization, \\
prevention, intervention
\end{tabular}

Kulcsszavak

anti-bullying program, autizmus, viktimizáció, prevenció, intervenció

\begin{abstract}
Anti-bullying approach applied among children with autism spectrum disorder in light of a professional literate review. The investigation of the phenomenon called bullying has started approximately five decades ago and simultaneously prevention and intervention programs have been developed. Shedding light on the concern of students with disabilities, such as children and adolescents with autism spectrum disorders has delayed. The focused programs for students with autism are still missing, though it is likely that the tools and aiming of prevention and intervention should not be irrespective of the nature and diagnosis of autism and the identified risk factors.
\end{abstract}

Absztrakt: A bullying jelenségének tudományos feltérképe-
zése közel öt évtizedes múltra tekint vissza, ezzel párhuza-
mosan került sor a prevenciós és intervenciós gyakorlatok
kialakítására. A fogyatékossággal élö tanulók - ezen belül az
autizmusban érintett gyermekek és serdülök - célcsoportként
való meghatározására némi késéssel került sor az érintett
tudományos és gyakorlati területen. Miközben továbbra is
hiátust jelent a célirányos programok kialakítása, valószínü-
síthető, hogy a diagnózistól és az azonosított rizikófaktorok-
tól nem függetleníthető a prevenció-intervenció eszközvá-
lasztása és célmeghatározása.

\section{Bevezetés}

A bullying az iskolai zaklatás nemzetközi szakirodalomban elterjedt megfelelője, , $a$ diákot zaklatás vagy elnyomás éri akkor, ha ismétlödöen és hosszú időn keresztül negativ cselekedeteknek teszi ki egy vagy több más diák" (Olweus 1999:717). 
Bullyingról akkor beszélhetünk, ha az az agresszív viselkedés vagy sérelemokozás szándékos, ismétlődően és tartósan fennáll, és olyan kapcsolatrendszerben valósul meg, ahol hiányzik a hatalmi egyensúly (Olweus 1999). A bullying kutatása a hetvenes években kezdődött (Dóczi-Vámos 2016). A jelenség közelebbi tudományos megismerésében élen járt Norvégia, Svédország, az Amerikai Egyesült Államok, Japán, Kanada, Anglia, Olaszország és Németország (Figula 2004). A jelenség hazai tudományos feltérképezése 2008-2009-ben vette kezdetét. A bullying kutatása eleinte a zaklatásban érintett egyénre koncentrált, és kezdetben jogtudományiigazságügyi valamint egészségügyi fókusszal bírt. A bullying jelenségével kapcsolatban elfogadott álláspont, hogy társas környezetben zajlik és a felek közti vélt vagy valós egyensúlyhiány sajátos szereprendszert hív életre, melyben korántsem csupán az elkövető és az áldozat jut szerephez. Bántalmazó, áldozat és szemlélő trialektikus egységet alkot, bármelyik aktor azonosítása feltételezi a másik két szerep meglétét is (Dóczi-Vámos 2017). A bullying komplex interperszonális folyamatának antiszociális oldalán találhatjuk a zaklatót, a csatlóst, a passzív zaklatót és a passzív támogatót, a proszociális oldalon a védelmezőt és a lehetséges védelmezőt, a semleges oldalon a közönyös bámészkodót (Olweus 2001, id. Dóczi-Vámos 2017). A jelenség érintettjei a társak, a felnőttek, a szülők, a családok, a szúkebb-tágabb kulturális és társdalmi közeg. Ez a szerteágazó érintettség, mint értelmezési keret hívta életre Espelage és Swearer ökológiai modelljét. (Dóczi-Vámos 2016). Az iskolai zaklatás megelőzésére irányuló anti-bullying programok jellemzően számos szerep és szereplő közremüködésével számolnak, ugyanakkor eltérő fókusszal bírnak. Bullying kapcsán prevenció és intervenció tekintetében aligha lehet éles határt húzni, legfeljebb súlypontozással jelölhető ki a különbségtétel (Metzig és Schuster 2010). Az éles elhatárolás ellehetetlenülése annyiban nem meglepő, hogy ahogy a drogprevenció esetében, úgy a bullying-prevenció kapcsán is az adott jelenség megléte és súlyossága hívja életre a prevenció igényét, vagyis a megelőzés egy jelen idejü, releváns problémára reflektál.

A témát érintő kutatások és a célzott beavatkozási programok történeti áttekintésére és rendszerezésére Peter K. Smith tett kísérletet 2011-ben, aki négy korszakot különített el egymástól. Az első korszakot „kezdetek” néven azonosítja, ami a tudományos érdeklődés kibontakozását jelenti 1970 és 1988 között és olyan kutatók és kutatócsoportjaik munkáját fémjelzi, mint Skandináviában Olweus, vagy éppen Angliában Peter Smith, Japánban Morita, Kanadában Craig és Pepler. Az első anti-bullying program is ehhez az időszakhoz köthető, melyet Olweus 1983-ben Norvégiában valósított meg Olweus Bullying Prevention Program (OBPP) néven. A második korszakot Smith a „kutatási programok megalapozása” címkével azonosítja, ami az 1989-1990-es évek közepére tehető. Skócia, Wales, az Amerikai Egyesült Államok, Kanada és Ausztrália széles spektrumú kutatásokkal kapcsolódik a fösodorhoz, az anti-bullying programok kidolgozására újabb példákat ad Belgium, Anglia és Kanada. A harmadik korszak a „,nemzetközi szintü kutatási programok” időszaka az 1990-es évek közepétől 2004-ig. A kutatások közös metszéspontokra találnak, a tudományos érdeklődés immáron kiterjed Németországra, Hollandiára, Belgiumra, Olaszországra, Spanyolországra, Portugáliára, csakúgy, mint Ázsiára. A volt szocialista országok közül Lengyelország jár élen a jelenség tudományos felfedezésében, kutatásában. Az egyre terjedő anti-bullying programok sokszínúséget mutatnak. A 2000-es évekkel kezdődő korszakot Smith a 
„cyberbullyng” elnevezéssel illeti, egyúttal utal a kutatás új irányaira és a jelenség terjedésének új terepére. Az online tér ugyanakkor nem csupán a bullying újabb színtere, hanem a virtuális tanulási környezet által a célzott beavatkozások egyik lehetősége is (Smith 2011, id. Dóczi-Vámos 2016).

Az anti-bullying programok kapcsán elterjedt fogalom az iskola-alapú program kifejezés, mely a célzott tevékenység helyszínét és az érintettek körét jelöli ki a kapcsolódó mikrokörnyezettel együtt. Mindezzel rokon az úgynevezett egész iskola koncepció is, amely szintén a kontextuális faktorokat hangsúlyozza, és amelynek első példájaként valósult meg az Olweus nevéhez köthető OBPP. Megkülönböztethetünk úgynevezett univerzális és válogatott vagy kijelölt tanulócsoportokra kialakított programokat, más felosztás szerint az egész iskolát, illetve a speciális iskolákat/osztályokat megcélzó beavatkozásokat, mindez kiegészül a komprehenzív / többoldalú program fogalmával. A szerzők többsége egyetért abban, hogy az egész iskolát érintő programok tekinthetőek univerzálisnak, míg más értelmezésben egy-egy osztályközösség alkotja az univerzális beavatkozás kiinduló egységét. A válogatott és kijelölt tanulócsoportok megcélzása bizonyos meghatározás szerint azon tanulók kiemelését és célzott intervencióját jelenti, akik meghatározott oknál fogva különösen veszélyeztetettnek bizonyulnak az bántalmazó magatartás vonatkozásában (Dóczi-Vámos 2016). Más szerzők, úgy, mint Farrell azonban kettéválasztják a válogatott és kijelölt tanulók halmazát. Válogatott programként tekintenek azokra a beavatkozásokra, melyek egy nagyobb csoport különösen veszélyeztetettnek mutatkozó részcsoportjára fókuszálnak, míg a kijelölt programok az egyén szintjén müködnek a kiemelten veszélyeztetett tanulók esetében (Farrell 2001, id. Dóczi-Vámos 2016). Wilson és Lipsey külön említést tesz a speciális iskolákra és osztályokra irányuló programokról és a komprehenzív/többoldalú programokról, melyek iskolai, osztálytermi, kiscsoportos és egyéni szinten egyaránt kijelölik az intervenció feladatait (Wilson és Lipsey 2005, id. Dóczi-Vámos 2016). További felosztás alapján megkülönböztethetőek a kompetenciák fejlesztését megcélzó és az ismeretek közvetítésére összpontosító programok, ezek összevetésében igazolódni látszik az előbbi kategória eredményessége. Vreeman és Carroll az anti-bullying programok tartalmi elemeit szem elött tartva direkt és indirekt megközelítést különít el aszerint, hogy a kompetenciafejlesztés kifejezetten a zaklatás témakörére szükül, vagy ennél tágabban értelmezhető, érintvén az önbecsülés kérdését, a pedagógus-tanuló interakciókat és az osztályközösségen belüli történéseket (Vreeman és Carroll 2007, id. Dóczi-Vámos 2016).

A programok hatékonyságát vizsgálva Ttofi és Ferrington arra jutott negyvennégy célirányos program vizsgálatát követően, hogy az anti-bullying beavatkozások átlagosan 20-23\%-kal csökkentik a zaklatás mértékét és 17-20\%-kal az áldozattá válás mértékét, de a finn KiVa, illetve a már említett norvég OBPP esetében 40-50\%-ra tehető a csökkenés (Ttofi és Ferrington 2011, id. Dóczi-Vámos 2016). Mindemellett nemzetközi szinten is hiányoznak az eltérő programokhoz illesztett hatásvizsgálatok, illetve az utánkövetés lehetőségének alkalmazása (Dóczi-Vámos 2016).

A bullying kiterjedt fogalomrendszerében önálló meghatározásként jelenik meg a viktimizációs veszélyeztetettség: „másokra nézve veszéllyel járó, kellemetlenséget, megaláztatást hozó, áldozattá-sértetté válást okozó, negatív kockázati tényezök, viselkedési formák" (Figula 2004:225). Ahogy a fogalom, úgy az antibullying programok felosztása is utal arra, hogy teljes egészében nem uniformizál- 
ható a prevenció-intervenció, hanem meghatározott kockázati csoportok speciális veszélyeztetettségét érdemes szem előtt tartani a megelözés és beavatkozás során. $\mathrm{Az}$ autizmusban érintett tanulók körében a bullying kulcsfontosságú kérdésnek bizonyul. Habár a bullyingban való érintettség terén a kapott prevalencia értékek nagy különbséget mutatnak - ami magyarázható az egyes kutatások definíciós különbségeivel, a választott mérőeszközök sokszínüségével, a mintaválasztás eltéréseivel -, az eredmények azt igazolják, hogy kiemelt kockázatú csoportként tekinthetünk az autista tanulókra (Hill és mtsai 2014). Gyakran idézett számadat, hogy a fogyatékossággal nem rendelkezö kortársakkal való összehasonlításban az autizmusban érintett tanulók körében négyszer valószínübb a viktimizáció valószínüsége (Sterzing és mtsai 2013). A jelenség nem leválasztható bizonyos diagnosztikus sajátosságokról, a viktimizációra hajlamosító rizikófaktorok közt azonosítható a szociális képességek deficitje, a kommunikációs nehézségek, a kevesebb számú vagy minőségében szegényesebb kortárskapcsolatok, az érzelemszabályozás nehézségei, a társuló internalizáló zavarok, a repetitiv és sztereotip viselkedés (Kloosterman és mtsai 2013; Nabuzoka 2003; Rowley és mtsai 2012; Schroeder és mtsai 2014; Zeedyk és mtsai 2014). A szociális interakciók zavara mellett a mások viselkedésének megértésében fellépő deficit szintén a kockázatot növeli (Frith és Hill 2004, id. van Roekel, Scholte és Didden 2009). Az esetlegesen társuló ADHD további rizikófaktorként nevesíthető (Montes és Haltermann 2007; Sterzing és mtsai 2012). Autizmus esetén a tipikustól eltérő érdeklődés és viselkedés, az áldozattá válásban tanúsított intenzív érzelmi és viselkedéses válasz egyúttal megerősítő, felbátorító hatással bírhat a zaklatói magatartást képviselő kortársakra, ami a rizikó erösödését jelenti. A szociális kapcsolatok nehézségei miatt az autizmusban érintett tanulók kevésbé élvezik a szupportív kortárskapcsolatok protektív faktorának előnyeit, ebből is fakad a kortárscsoporton belül kialakult marginalizált helyzet, ami szintén kockázati tényezőként nevesíthető (Cappadocia, Weiss és Pepler 2011). Autizmusban érintett tanulók bullying-kutatásában jellemzően különbségek mutatkoznak az egyazon kutatásban résztvevő válaszadóktól (pedagógus, szülő, kortárs versus érintett tanuló) kapott eredményekben, amire magyarázatként szolgálhat az autizmus magdeficitjeként említett tudatelméleti sérülés (Hill és mtsai 2014). A tudatelmélet vagy mentalizáció azt a képességet jelöli, hogy az egyén számára érzékelhető és értékelhető a saját és a másik fél mentális állapota, képes szándékokat, elképzeléseket és vágyakat beazonosítani, illetve sajátjait megkülönböztetni másokétól (Premack és Woodruff 1978). A tudatelméleti deficit az autizmus kapcsán jellemzően fennálló probléma, ami nagy mértékben befolyásolja a szociális interakció, így a bullying folyamatának interpretációját is.

\section{Módszer}

A szakirodalmi áttekintés célja az autizmusban érintett tanulók bullying kutatásához kapcsolódó anti-bullying stratégiák, ajánlások és megvalósult programok azonosítása és bemutatása. A keresés az ,autism”, „,bullying”, „prevention” kifejezések segítségével történt a PubMed adatbázisában 2019. május 5-én. A keresés összesen ti- 
zenhat találatot adott. Az azonosított tanulmányok áttekintését követően a találati lista szükítésére került sor, azok a közlemények maradtak fenn, melyek kifejezetten az autizmusban érintett populáció vizsgálatára irányultak a bullying kérdéskörében. Ez alapján hét cikket sikerült azonosítani. Ezt követően kizárásra került két közlemény, ami nem empirikus munkát ismertet, illetve az autizmusban érintett személyek halmazánál lényegesen tágabban határozza meg a vizsgálati mintát („neurodevelopmentális problémák”). Ilyen módon a találati lista öt tanulmányra szükült. A kutatási eredmények ismertetése mellett a fókusz mindenekelőtt az eredmények alapján kirajzolódó anti-bullying stratégiák vázolása, ami jelentheti teoretikus ajánlások bemutatását, és már életbe léptetett, megvalósult programok ismertetését. A szóban forgó öt közlemény közül három tesz ajánlást a gyakorlati megvalósításra nézvést, míg két publikáció esetében megvalósult programok bemutatására és értékelésére került sor.

\section{Eredmények}

Cappadocia, Weiss és Pepler (2012) autizmus spektrum zavarral élő gyermekek és adoleszcensek körében vizsgálták a bullyingban való érintettséget, valamint a jelenséget érintő védő- és rizikófaktorokat. A válaszadó gondviselők/szülők 77\%-a jelezte, hogy a vizsgálatot megelőző egy hónapban érte zaklatás a gyermekét, 11\% egyetlen alkalomról számolt be, 23\%-uk két-három alkalomról adott jelzést, 13\%-uk heti egy alkalomra utalt, 30\%-uk pedig heti két, vagy annál is több alkalmat jelölt meg a zaklatás gyakoriságaként. Azok a gondviselök/szülök, akik a vizsgálatot megelőző hónappal kapcsolatban jelezték a zaklatás előfordulását, eltérő időtartamú zaklatói periódusokat konkretizáltak. A válaszadók 6\%-a egy hétben, 2\%-uk két hónapban, 20\%-uk néhány hónapban, 9\%-uk egy évben, 54\%-uk több mint egy éves időtartamban határozta meg a zaklatás előfordulásának időhosszát. 9\% esetében nem hozzáférhető a zaklatás időtartamára vonatkozó adat. A válaszok alapján a gyermekek 68\%-a zaklatás több formáját (fizikai, verbális, kapcsolati zaklatás és cyberbullying) is elszenvedi. A leggyakoribbnak a verbális és kapcsolati zaklatás bizonyult (Cappadocia, Weiss és Pepler 2012).

Cappadocia, Weiss és Pepler kutatásában az életkor, a kommunikációs nehézségek, az internalizációs zavarok, az iskolai barátok száma és a szülők mentális egészsége prediktív tényezőnek mutatkoztak a viktimizáció gyakoriságának tekintetében. A viktimizációban egyáltalán nem (vagy maximum egy alkalommal) érintett gyermekekhez képest az érintett gyermekek körében ötször valószínübb volt a kommunikációs nehézségek terén elért magas érték és tizenegyszer valószínübb volt az internalizációs zavarok terén kapott magas érték. A viktimizációban érintettek a nem viktimizált csoporthoz képest jellemzően fiatalabbak voltak és szegényes baráti kapcsolatokkal rendelkeztek (Cappadocia, Weiss és Pepler 2012).

A szerzők a prevenció és intervenció lehetőségei közt a felnőttek felelősségét hangsúlyozzák az esetlegesen hátrányos helyzetet teremtő természetes dinamika kibontakozásának ellensúlyozására. Így például az osztálytermi ültetés gyakorlatát a spontán történő padtársválasztás helyett vagy csapatsportok esetén a csapatok kijelö- 
lését a csapatkapitányok egyedi választása helyett. Ez a típusú szociális architektúra önmagában preventív erejü lehet a peremhelyzetre sodródással, és így következményesen a viktimizációval szemben: „A pozitív szociális architektúrán keresztül a viktimizációval szemben vulnerábilis, marginalizált státuszú gyermekek védelmet kapnak és a szociális inklúzió maximuma érhetö el. (Cappadocia, Weiss és Pepler 2012:272-273). A felnőttek felelősségének tárgyalása során nem elhanyagolható, hogy a jelenlévő felnőttek egyúttal szerepmodellként is funkcionálnak. Másrészt ők egyúttal a kortársak közti kapcsolati dinamika szemtanúi is. Ha az elkövető magatartása és hatalomgyakorlása nagy figyelmet kap, ez megerősítő hatással bír és tartósan fenntartja a bántalmazás aktusát, míg ha a szemtanúk közbeavatkoznak, a bántalmazás megszakítható (Cappadocia, Weiss és Pepler 2012). Salmivanelli és munkatársai négy eltérő szerepet különböztetnek meg a bántalmazás szemlélöinek körében: „az asszisztáló”, „a megerősítő”, „a kívülálló” és ,,az áldozat védelmezője” szerepeket (Salmivanelli és mtsai 1996, id. Cappadocia, Weiss és Pepler 2012). A prevencióintervenció feladatai közé tartozik a kortársak védelmező szerepének erősítése, illetve annak tudatosítása, hogy jelenlétük befolyásoló erővel bír, és a megerősítés hatása csökkenthető a szemlélö szerepe által. Szintén a pedagógusi feladatok közt kerül említésre a fogyatékosság kérdéskörével kapcsolatos ismeretátadás, a kortársak közti negatív interakciók korai azonosítása, valamint a pozitív interakciók facilitálása és ezen keresztül az inklúzió erősítése. A felnőttek jelenléte és segítsége tehát kritikus jelentősséggel bír, akár a szociális képességek fejlődésének azon területein is, mint az adaptív érzelemreguláció és viselkedésszabályozás stratégiáinak elsajátítása, a megküzdési képességek, a kortársak felől érkező provokáció ignorálása, a támogató kortársak azonosítása, a problémamegoldás és az asszertív kommunikáció (Cummings és mtsai 2006, id. Cappadocia, Weiss és Pepler 2012). Támogatott a szülöi részvétel a szociális képességek tanulása-tanítása során (Frankel és mtsai 2010; Laugeson és mtsai 2009, id. Cappadocia, Weiss és Pepler 2012). Fontos üzenet a gyermek felé a felnőttektől való segítségkérés szükségessége, ami egészen addig terjedhet, amíg megértésre és védelemre nem talál a viktimizálódott gyermek (Cummings és mtsai 2006, id. Cappadocia, Weiss és Pepler 2012). Természetesen a bullyingból adódó egyéni következmények a mentális egészség romlásában szükségessé tehetik az egyén individuális megsegítését, akár pszichoterápia által is. Ugyanakkor nem elegendő csupán az áldozat személyét megcélozni a bullying felszámolását, enyhítését szándékozó beavatkozás során, hiszen a proaktív és modellértékü felnőtt személy szerepe vitathatatlan a kortársak befolyásolásában, a befogadásra irányuló edukációban és a befogadás ösztönzésében. Az univerzális bullying prevenciós programok szintén nem elvetendőek, különösen, ha a teljes iskola bevonódását feltételezik. Ezek a programok többnyire szintén egy edukációs folyamatot takarnak, elsősorban a bullying és az iskola bullyinggal kapcsolatos irányelveire vonatkozóan, fókuszba kerülnek a bullying eltérő típusai (fizikai, verbális, kapcsolati és cyberbullying), a bullyingból fakadó erőegyenlőtlenség, a biztonsághoz való jog, a szemlélők felelőssége az áldozatokkal szemben. Ezek a programok akkor bizonyulnak hatásosnak, ha tartósan müködtethetőek és beépülnek az iskola formális és nemformális tantervébe (Cummings és mtsai 2006, id. Cappadocia, Weiss és Pepler 2012). Az univerzális programok eredményességének elemzését követően azonban kirajzolódik az is, hogy azok a tanulók, akik intenzíven és tartósan bántal- 
maznak, intenzívebb támogatásra szorulnak, az áldozatok pedig kiterjedtebb intervenciót igényelnek a bántalmazók és a bántalmazás elkerülése érdekében (Pepler és mtsai 2006, id. Cappadocia, Weiss és Pepler 2012)

Fisher és Taylor (2016) kvalitatív kutatása a viktimizáció szubjektíven megélt élményszerüségét tárja fel autizmusban érintett tanulók körében. Az eredmények egyértelmüen alátámasztják, hogy a bullying jelenségének megélése és interpretációja különbözik a vizsgált csoportban a neurotipikus tanulók önbevallásos alapon regisztrált élményeihez képest. A viktimizációban érintett tanulók a bántalmazás okai közt személyes attribútumokat jelöltek meg (saját magukat hibáztatták, „könnyü prédának" minősülnek, felismerhető fogyatékossággal rendelkeznek), valamint a mások által kialakított véleményeket (negatív vélemény és elutasítás) jelölték meg kiváltó okként. A viktimizációra adott reakciók közt megjelenik az adott pillanatban adott válasz (a zaklató mellőzése, érzelmek kontrollálása, asszertivitás), az esemény után adott válasz (pedagógusnak és/vagy szülönek jelezni a problémát, a jelzés késleltesése az iskola befejeztéig, saját viselkedés módosítása, történtek lejegyzése). Megjelenik továbbá a megtorlás igénye (az esemény pillanatában vagy azután, fenyegetőnek mutatkozni), a minimalizálás igénye (a helyzet súlyosságát alábecsülni, bagatellizálni), a bántalmazó és áldozat közti kapcsolat megváltozása (bizalomvesztés, bosszantónak értékelni az elkövetőt) (Fisher és Taylor 2016).

Az eredményekre alapozva a szerzőpáros viselkedésmenedzsment-alapú beavatkozást javasol a bullying megelőzésére (Fisher és Taylor 2016). Fisher és Taylor számos más szerzővel egyetértésben hangsúlyozza, hogy az oktatás-nevelés terén megvalósuló inklúzió a gyakorlatban nem magától értetődően jár együtt a szociális inklúzióval (Harrower és Dunlap 2001; Hughes és mtsai 2002, id. Fisher és Taylor 2016). Az együttnevelés során a neurotipikus tanulók ellenállása, az esetleges félelem és negatív attitüd nehezíti az érdemi inklúzió megvalósulását és a fogyatékossággal élő tanulók kapcsolati hálójának egészséges fejlődését. Ebből kifolyólag az anti-bullying célkitűzésű beavatkozások nem kerülhetik meg az inklúzió kérdését és a neurotipikus tanulókat (Fisher és Taylor 2016). A proszociális viselkedés és az attitüdváltozás támogatásának módszereként a szerzők a kortárssegítést nevezik meg. Ennek keretében a nem fogyatékos tanulók aktív tevékenykedő szerepbe lépnek és egyúttal modellszemélyként funkcionálnak a többi tanuló számára is, így nem csupán a kortárssegítők körében remélhető az attitüd- és viselkedésváltozás, de a többi tanuló részéről is (Copeland és mtsai 2004 id. Fisher és Taylor 2016). A kortárssegítés, mint antibullying stratégia és a hatékonyság igazolásának igénye további kutatási feladatokat jelöl ki. Mindemellett a bullying prevenció értelemszerűen az áldozati csoportra, tehát az autizmusban érintett tanulókra irányul. A kvalitatív kutatás eredményeinek értelmében az autizmusban érintett tanulók jól körvonalazható válaszokkal reagálnak az őket célzó bullying jelenségére, a bullying prevenció feladata, hogy segítse a lehetséges áldozatokat a hatékony és kevésbé hatékony válaszreakciók megkülönböztetésében. Ezzel párhuzamosan a pedagógusok támogatása is szükségesnek mutatkozik abban a tekintetben, hogy kompetensen és megfelelően reagáljanak az esetleges áldozati jelzésekre, amellett, hogy modellszemélyként funkcionálnak a nem fogyatékos tanulók számára (Cappadocia, Weiss és Pepler 2012; Schroeder és mtsai 2014; id. Fisher és Taylor 2016). További szempontokat vet fel az, hogy az autizmusban érintett fiatalok gyakran az események következményeinek minimalizálásával, bagatellizálással, vagy 
a kortárskapcsolatok megváltozásával reagáltak az őket érő bullyingra. A viktimizációs érintettség a továbbiakban gátolta az érdemi kortárskapcsolatok kialakulását, kibontakozását. További kutatási feladat a bullying azonnali és késletetett hatásainak összevetése, annak érdekében, hogy prevenciós beavatkozások révén facilitálni lehessen a további minőségi kortárskapcsolatok kialakítását és fenntartását. Miközben az általános bullying prevenció jól körvonalazható elemeket tartalmaz (zéró tolerancia alapelv, pozitív viselkedési stratégiák támogatása), a változó hatékonyság mellett figyelemreméltó, hogy az anti-bullying programok adaptációjára nem került sor az áldozati csoportra szabottan, emellett az individualizált beavatkozás is a hatékonyság irányába mutató elvárásnak mutatkozik. Fisher és Taylor olyan viselkedésmódosítási programok teljesítésében lát potenciált, ami magában foglalja a szociális képességek fejlesztését, mentálhigiénés konzultációt és a viselkedést érintő egyéb képességekre kiterjedő tréninget, amellett, hogy az adaptált anti-bullying program törekvései közt kell szerepelni a a kortársak edukálásának és a kortárssegítés kiépítésének és facilitálásának (Fisher és Taylor 2016).

Weiss és Fardella (2018) autizmusban érintett felnőtteket vizsgált neurotipikus felnőttekkel való összevetésben az őket érintő viktimizáció és elkövetői magatartás kérdéskörében. A gyermekkorban tapasztalt viktimizáció kérdését körüljárva az autizmusban érintettek 6,7-szer nagyobb valószínüséggel számoltak be tulajdont érintő károkozásról, ezen belül a lopás valószínüsége is lényegesen magasabb volt. Neurotipikus felnőttek önbevallásos válaszaival való összevetésben az autista csoporton belül 4-szer valószínübb a felnőtt elkövető részéről történt gyermekkori bántalmazás, köztük a fizikai, pszichológiai és érzelmi bántalmazás. 27,1-szer valószínübb a kortársak részéről tanúsított verbális bántalmazás, 3,7-szer valószínübb a bullying egyéb megnyilvánulása a kortárscsoportban, 7,3-szor valószínübb a kortárs által elkövetett szexuális zaklatás. Összességében az autizmusban érintettek szignifikánsan nagyobb arányban számoltak be a gyermekkort érintő krónikus poliviktimizációról, mint a neurotipikus csoportban. A felnőttkorban tapasztalt élményeket illetően 2,7-szer magasabb a verbális bántalmazás valószínüsége az autizmusban érintettek körében, illetve valószínübb a szexuális zaklatás valószínüsége is, elsősorban ismert elkövető által. Ugyanakkor az autista válaszadók nem számoltak be nagyobb mértékü felnőttkorban tapasztalt poliviktimizációról, mint a neurotipikus csoport válaszadói. A válaszadók összehasonlításában a felnőttkori elkövetés terén sem mutatkozott jelentős különbség az eltérő bántalmazási típusok egyikében sem. Korábbi kutatási eredményeket megtámogatva az autizmusban érintett csoportban kevésbé fejlett szociokommunikációs kompetenciára és érzelemregulációs képességekre utalnak az eredmények, ugyanakkor meglepő módon sem a szociokommunikációs kompetencia, sem az érzelemregulációs képességek nem korreláltak szignifikánsan a gyermekkori, illetve a felnőttkori poliviktimizációval egyik csoportban sem. Így a szerzők - más kutatóktól eltérően - ezen tényezők szerepét nem veszik számba prevenciós-intervenciós ajánlásaik megfogalmazása során (Weiss és Fardella 2018).

Weiss és Fardella az erősségekre fókuszáló iskolai programok szükségességét látja indokoltnak a viktimizáció előfordulásának csökkentésére, amellett, hogy ezen beavatkozások hatékonyságnak igazolása további vizsgálatokat igényel. Az a megállapítás, hogy az autizmusban érintett felnőttek körében nagyobb mértékü az érzelmi és 
verbális bántalmazás, élethosszon keresztül fennálló rizikóra hívja fel a figyelmet. Ennélfogva az autista felnőtt munkavállalóként vagy a közösség tagjaként is jelentősen profitálhat olyan programok megvalósításából, melyek a bántalmazás és bullying, illetve az ezzel kapcsolatos helyzetkezelés kérdését járják körül. A szerzőpáros olyan program megvalósítását látja szükségesnek, mely eltérő kontextusban - otthoni, iskolai, munkahelyi, közösségi szinten - célozza meg az egészséges kapcsolati müködés és az inklúzió igényének teljesülését. Azzal együtt, hogy sem a szociokommunikációs kompetencia, sem az érzelemreguláció képessége nem minősültek mediátornak a viktimizációs vulnerabilitás irányába, további egyéni és kontextuális tényezők vizsgálata szükségesnek mutatkozik a jövőben (Weiss és Fardella 2018).

Liu és munkatársai (2018) a tudatelméleti tréning hatását vizsgálták a bullying jelenségével szemben magasan funkcionáló autista gyermekek és adoleszcensek körében. Míg a vizsgálat során az egyik csoportban a tudatelméleti tréning képezte az intervenció módszerét heti rendszerességgel, addig az összehasonlításhoz szükséges másik csoportban szociális képességfejlesztés tréning zajlott szintén heti egy alkalommal. A résztvevők és a szülők egyaránt értékelték a bullyingban való áldozati és elkövetői érintettséget a lezajló tréninget megelőzően és azt követően (Liu és mtsai 2018).

A szerzők a tudalelméleti tréning eszközválasztását megindokolva utalnak arra, hogy az autizmusra jellemző tudatelméleti deificit negatív hatást gyakorol a szociális interakciókra. Sérülnek a szociális kapcsolatok, mert az autizmusban érintettek érzelmi és viselkedéses válaszai függnek mások mentális státuszának megítélésétől. Alacsony szintü empátiás készség és mások szándékainak téves értelmezése esetén ez a nehézség alapvetően fennáll (Liu, és mtsai 2018). Szintén nem független a tudatelmélet fogalmától, hogy az autizmusban érintett személyek számára a bullyingként nevesülő helyzetek azonosítása nehézségbe ütközhet, az érintett áldozat mások attitüdjére és viselkedésére inadekvát módon reagálhat, ami következményesen növeli a bullying kockázatát (Sterzing és mtsai 2012, id. Liu és mtsai 2018). Mindemellett a tudatelmélet sérülése csökkenti a baráti kapcsolatok kialakulásának valószínüségét, így kevésbé lehet számolni az iskolán belüli szociális védettséggel és a kortársak védelmező asszisztenciájával akkor, amikor az autista tanulót bántalmazás éri (Liu, és mtsai 2018).

Mindkét intervenció heti egy ülésben zajlik két életkori (10-14 éves és 15-18 éves) csoportban, tíz héten keresztül. A tudatelméleti tréning az érzelmek megértésének és a hiedelemekhez köthető attribúció szintjén dolgozik Howlin és munkatársainak munkája nyomán. Az érzelemfelismerés érinti az arckifejezések dekódolását, a helyzet-, vágy- és hiedelemalapú érzelmeket. A tematikában megjelennek az első és második szintű téves hiedelmek, a nem szó szerint értendő nyelv, az úgynevezett kegyes hazugság és a szarkazmus. A tréning során az instruktor a bullying helyzetét egyúttal szemléltetéséként is használja az érzelmek tudatosításának eszközeként. Mindezzel összevetésben a szociális képesség tréning a mindennapi élet íratlan szociális szabályaira fókuszál, a tematika érinti a megfelelő öltözködés és étkezés kérdését, az elfogadott szociális interakciós protokollt, a baráti jellegü kapcsolatteremtés iránymutató szabályait. A tréning Liu módszerét adaptálja. Az instruktor ez esetben is illusztrációként alkalmazza a bullying lehetséges helyzeteit, mindenekelőtt a szükséges szociális képességek elmélyítésében. Mindkét tréningben közös, hogy 
nagy figyelmet szentel a szociális problémamegoldásra, az impulzuskontrollra, a társalgási szabályokra, a frusztráció- és stresszkontrollra. Mindkét intervenció kognitív viselkedésterápiás elméleti alapokon nyugszik azzal a különbséggel, hogy míg a tudatelméleti tréning motivációs és viselkedéses alapelveket követ, addig a szociális képesség tréning a viselkedés szintjére alapoz.

Az önbevallásos és a szülőktől kapott válaszok alapján a tréningeket megelőzően nem mutatkozott szignifikáns különbség a két csoport összehasonlításában sem az elkövetést, sem a viktimizációt illetően. A tudatelméleti tréninget követően az önbevallásos és a szülői válaszok szerint szignifikánsan csökkent a viktimizáció aránya. Az elkövetés terén nem mutatkozott szignifikáns különbség a tréninget megelőző és azt követő mérés szerint sem a szülök, sem az érintettek szerint. A szociális képességfejlesztés tréning mérései alapján az önbevallásos válaszokat követve szintén szignifikáns különbség mutatkozott a viktimizáció súlyosságának tréninget megelöző és azt követő állapota szerint, ugyanakkor a szülői válaszok alapján nincs szignifikáns különbség. Szintén nem mutatkozott különbség az elkövetés terén a tréninget megelőzően és azt követően. Az adatok további elemzését követően a szülöi válaszok alapján a tudatelméleti tréning hatása a bullyingban való érintettség befolyásolására ígéretesebbnek mutatkozik, mint a szociális képességfejlesztés tréning esetében (Liu és mtsai 2018).

Habár a tudatelméleti tréning sikerességének oki feltárása és pontos mechanizmusainak feltérképezése további vizsgálatokat igényel, feltételezhető, hogy a kommunikációs képesség fejlődése által mutatkozik eredményesnek a bullying visszaszorításában. Mindez annak következménye, hogy a tudatelméletre ható beavatkozás során az egyén képessé válhat szimultán számba venni saját és a másik fél mentális állapotát. A szociális tér történéseinek pontosabb megértése révén fejlödhet az adaptív szociális viselkedés, így többé-kevésbé bejósolható mások viselkedése és elkerülhető a zaklató személye. Másrészt megtapasztalható, hogy a saját és mások mentális állapota változhat új információk hatására, így a viktimizáció tapasztalatából kiindulva új alternatív szociális interakciós minták fejleszthetőek ki. A tudatelméleti teljesítmény javulásának következtében a szülő-gyermek interakciók hatékonyabbá válhatnak, vagyis hipotetikusan megerősödhet az a kapcsolat és ,jelzőrendszer”, mely a bullyingban való érintettséget első ízben érzékeli (Liu és mtsai 2018)

Sreckovic, Hume és Able (2017) azt vizsgálták, hogy a kortárshálózatra épülő intervenció milyen hatást gyakorol az autizmus spektrum zavarban érintett (de társuló értelmi akadályozottsággal nem rendelkező) és neurotipikus középiskolás tanulók szociális interakcióira nézvést, illetve hogy az intevenció hatással van-e az autizmusban érintett tanulók viktimizációjának gyakoriságára. Az intervenció célcsoportját három autizmusban érintett tanuló alkotta, akik a meghatározott kritériumok alapján mindannyian többségi iskolába jártak, nem rendelkeztek társuló értelmi akadályozottsággal, a pedagógusi beszámoló alapján kevés vagy szegényes kortárskapcsolatokkal rendelkeztek és áldozatként érintettek a bullyingban. A kortárssegítő csoportba tizennégy tanuló került, akik a célcsoporttal és az iskola konzultánsával történő egyeztetés alapján partneri viszonyra alkalmasnak mutatkozott, illetve hasonló érdeklődési területtel rendelkezett, mint a célcsoportba tartozók. A célcsoport egyes tagjaival személyenként három, öt illetve hat kortárssegítő müködött együtt. A célszemély és a kortárssegítő között megszervezett találkozások során rögzítésre kerültek a kezdeménye- 
zések és kérdések, a viktimizációs érintettséget az intervenciót megelőzően és azt követően kitöltött kérdőíven (BVS) keresztül lehetett értékelni. Az intervenció tartalmában Carter és munkatársainak 2013-as ajánlásait követi, aminek része a kortárssegítőknek szervezett felkészítő találkozó, az ismerkedő találkozó (ahol minden résztvevő érintkezik és kialakulnak a célszemélyekből és kortárssegítőkből álló hálózatok), a kortárshálózati találkozók sorozata (ahol az egyazon hálózatban dolgozó kortársak és egy facilitátor konzultálnak) és a fenntartási időszak (mely a generalizálhatóságra adott rálátást). A célszemély-kortárs találkozások az ebédszünetekben valósultak meg. $\mathrm{Az}$ eredményeket tekintve növekedett a szociális interakciók aránya, a fenntartási időszakban (tehát a tényleges intervenció lezárta után) két tanuló esetében stabil és konzisztens maradt a szociális interakciók aránya az intervenciós időszakhoz képest, egy tanuló esetében kezdeti enyhe csökkenés mutatkozott, amit emelkedés követett. Összességében a bevezető időszak és a fenntartási időszak összehasonlításában, tehát pre- és posztintervenciós időszakok összevetését tekintve növekedés mutatkozott a szociális interakciók arányában. Ez azt is jelenti, hogy az autizmusban érintettek kezdeményezéseiben és válaszadásaiban emelkedés észlelhető a kezdeti és fenntartási időszakot összevetve. Hasonlóképpen a kortársak kezdeményezéseiben és válaszadásaiban is emelkedés mutatkozott autista társaik irányában. A bullying viktimizációt mérő kérdőív (BVS) alapján kapott eredmények eltéréseket mutatnak. Egy tanuló (1-es számú célszemély) esetében minimálisan csökkent a viktimizációs érintettség, miközben a kérdőív felvételének eltérő időpontjaiban mindvégig átlagos érintettséget produkált. Egy tanuló (2-es számú célszemély) esetében nem mutatkozott változás alacsony viktimizációs érintettség mellett. Egy tanuló (3-as számú célszemély) esetében jelentős változás jelentkezett: preintervenciós szakaszban súlyos viktimizációs érintettség mutatkozott, ami a kezdeti szakaszban is fennáll, majd az intervenciós időszakban klinikailag szignifikáns súlyosság észlelhető, ami fenntartási szakaszt követően már átlagos érintettséget jelent. A szerzők hipotetikusan megállapítják, hogy a szociális interakciók arányának növekedése és a baráti kapcsolatok erősödése kapcsolatban állhat a viktimizáció csökkenésével, így a kortárshálózatra épülő intervenció a szociális interakciók arányának befolyásolásán túl a viktimizáció csökkentésének eszközeként is hasznosulhat. A szerzők a kortárssegítés számos előnyét hangsúlyozzák, a kortársak a felnőttekhez képest jártasabbak az adoleszcensek közt elfogadhatónak tartott szociális interakciók protokolljában és aktuális szociális történésekben. Miközben a neurotipikus tanulók vonakodhatnak az autizmusban érintett társaikkal való érintkezéstől, a kortárssegítők bevonása nem csupán alkalmat teremt a szociális interakciókra, de egyúttal a többi neurotipikus tanuló számára is élő példát ad a kapcsolatteremtésre, ami az intervenció nélkül nem realizálódna (Sreckovic, Hume és Able 2017).

\section{Diszkusszió}

A vizsgált közlemények példázzák, hogy az univerzális programokhoz hasonlóan az autizmusban érintett populáció számára müködtetett/müködtethető prevencióintervenció is számos, a jelenségben érintett szereplö és változás elöidézésére alkalmas 
aktor bevonásával valósulhat meg. Abban eltérések mutatkoznak, hogy mely szinten válik hangsúlyossá a beavatkozás, vagyis, hogy az iskolapolgárok közül ki az az aktor, akitől a közbelépés elsődlegesen várható, ugyanakkor az a tendencia erösödik, hogy a kortársakra egyre nagyobb és hangsúlyosabb feladatok ruházhatóak.

\begin{tabular}{|c|c|c|c|c|}
\hline Szerző & Kutatási kérdés & $\begin{array}{l}\text { Ajánlás (A) vagy } \\
\text { megvalósítás }(M) ?\end{array}$ & Hozzárendelt eszköz & $\begin{array}{l}\text { Mely szinten hangsú- } \\
\text { lyos a feladatvállalás }\end{array}$ \\
\hline $\begin{array}{l}\text { Cappadocia, } \\
\text { Weiss és } \\
\text { Pepler, } 2012\end{array}$ & $\begin{array}{l}\text { Prevalancia, védő- és } \\
\text { rizikófaktorok }\end{array}$ & A & $\begin{array}{l}\text { Pozitív szociális } \\
\text { architectúra }\end{array}$ & - Felnőtt \\
\hline $\begin{array}{l}\text { Fisher \& } \\
\text { Taylor, } 2016\end{array}$ & $\begin{array}{l}\text { Bullying szubjektív } \\
\text { élményszerüsége }\end{array}$ & A & $\begin{array}{l}\text { Viselkedésmenedzsment- } \\
\text { alapú beavatkozás }\end{array}$ & $\begin{array}{ll}\text { - } & \text { Felnőtt } \\
\text { - } & \text { Kortárs }\end{array}$ \\
\hline $\begin{array}{l}\text { Weiss \& } \\
\text { Fardella, } 2018\end{array}$ & $\begin{array}{l}\text { Autista felnőttek } \\
\text { érintettsége a } \\
\text { bullyingban }\end{array}$ & A & $\begin{array}{l}\text { Erősségekre fókuszáló } \\
\text { iskolai programok, eltérő } \\
\text { kontextusok számbavétele }\end{array}$ & (nem megnevezett) \\
\hline $\begin{array}{l}\text { Streckovic, } \\
\text { Hume és Able, } \\
2017\end{array}$ & $\begin{array}{l}\text { Kortárshálózatra } \\
\text { épülő intervenció } \\
\text { hatása }\end{array}$ & M & $\begin{array}{l}\text { Kortárshálózatra épülő } \\
\text { intervenció } \\
\text { (kortárssegítés) }\end{array}$ & - $\quad$ Kortárs \\
\hline $\begin{array}{l}\text { Liu és mtsai, } \\
2018\end{array}$ & $\begin{array}{l}\text { Tudatelméleti tréning } \\
\text { hatása }\end{array}$ & $\mathrm{M}$ & Tudatelméleti tréning & - Felnőtt \\
\hline
\end{tabular}

A viktimizációs veszélyeztetettség fogalmának relevanciája igazolódik, ahogy az anti-bullying programok differenciálásának igénye is létjogosultságot nyer annak tükrében, hogy az autizmus önmagában véve meghatározott rizikófaktorokat jelez a bullying vonatkozásában, és ezekre célzottan reagálnia kell a programoknak. Mindezek fényében nem meglepö, hogy a müködtetett/müködtethető antibullying programok mindenekelőtt a kompetenciafejlesztésre helyezik a hangsúlyt, amellett, hogy nem nélkülözik az ismeretátadás eszközeit sem. Utóbbira elsősorban Cappadocia, Weiss és Pepler ajánlásai közt találtunk példát a kortársak inklúzió felé ható edukációja kapcsán (Cappadocia, Weiss és Pepler 2012). A kompetenciafejlesztés elsősorban indirekt megközelítésben képzelhető el, vagyis az érintett képességek széles körét megcélozza a bullying konkrét, szüken értelmezett szociális interakcióján túl. Ennek markáns példáját adja a tudatelméleti tréning, mely a teljes társkapcsolati müködést befolyásolni hivatott (Liu és mtsai 2018). Ahogy a neurotipikus tanulók számára kialakított anti-bullying programok terén, úgy az autizmusban érintett tanulókat megcélzó prevencióintervenció tekintetében sem találunk konzisztens megoldásokat. Ez nem csupán a jelenség kevésbé kutatott voltára mutat rá, de azt az alapvetést is támogatja, hogy az uniformizálás és a standard megoldásokra való törekvés elsődlegessége még egy ilyen szükre szabott célcsoporton belül sem célravezető. Emiatt is mutatkozik szükségesnek az adott célcsoport bullying jellemzőinek további kutatása, a prevenció-intervenció gyakorlati megvalósításának hangsúlyozása, melyet utánkövetés és hatásvizsgálatok egészítenek ki. 


\section{Hivatkozott irodalom:}

1. Cappadocia M. C., Weiss J. A., Pepler D. (2012) Bullying Experiences Among Children with Autism Spectrum Disorders. Journal of Autism and Developmental Disorders 42 (2.) 266-277.

2. Dóczi-Vámos G. (2016). Az iskolai erőszak és zaklatás megelőzésére és visszaszorítására irányuló beavatkozási programok metaelemzése. Neveléstudomány 4. (2.) 67-79.

3. Dóczi-Vámos G. (2017). Az iskolai agresszió fogalmi köre - egy lehetséges rendszerezés. Neveléstudomány 5 (4.) 68-80.

4. Figula E. (2004). Bántalmazók és bántalmazottak az iskolában. Új pedagógiai szemle 54. (7-8.) 223-228.

5. Fisher M. H., Taylor J. H. (2016). Let's talk about it: Peer victimization experiences as reported by adolescents with autism spectrum disorder. Autism 20 (4.) 402-411.

6. Hill A. E., Zuckerman K. E., Hagen A. D., Kriz D. J., Duvall S. W., van Santen J., Nigg J., Fair D., Fombonne E. (2014). Aggressive behavior problems in children with autism spectrum disorders: Prevalence and correlates in a large clinical sample. Research in Autism Spectrum Disorders 8. (9.) 1121-1133.

7. Kloosterman P. H., Kelley E. A., Craig W. M., Parker J. D. A., Javier C. (2013). Types and experiences of bullying in adolescents with an autism spectrum disorder. Research in Autism Spectrum Disorders 7 (7.) 824-832.

8. Liu M. J., Ma L. Y., Chou W. J., Chen Y. M., Liu T. L., Hsiao R. C., Hu H. F., Yen C. F. (2018). Effects of theory of mind performance training on reducing bullying involvement in children and adolescents with high-functioning autism spectrum disorder. PLoS One 13 (1.)

9. Metzig W., Schuster M. (2010). Agresszió az iskolában. Elméleti háttér, előfordulás, beavatkozás és megelőzés. In: Hárdi I. (eds.) Az agresszió világa (223251). Budapest: Medicina Könyvkiadó.

10. Montes G., Halterman J. S. (2007). Bullying among children with autism and the influence of comorbidity with ADHD: a population-based study. Ambulatory Pediatrics 7 (3.) 253-257.

11. Nabuzoka D. (2003). Teacher ratings and peer nominations of bullying and other behavior of children with and without learning difficulties. Educational Psychology 23. (3.) 307-321.

12. Olweus D. (1999). Az iskolai zaklatás. Educatio 8 (4.) 713-739.

13. Premack D. G., Woodruff G. (1978). Does the chimpanzee have a theory of mind? Behavioral and Vrain Sciences 1 (4.) 515-526.

14. Rowley E., Chandlar S., Baird G., Simonoff E., Pickles A., Loucas T., Charman T. (2012). The experience of friendship,victimization and bullying in children with an autism spectrum disorder: Associations with child characteristics and school placement. Research in Autism Spectrum Disoders 6 (3.) 1126-1134.

15. Schroeder J. H., Cappadocia M. C., Bebko J. M., Pepler D. J., Weiss J. A. (2014). Shedding Light on a Pervasive Problem: A Review of Research on 
Bullying Experiences Among Children with Autism Spectrum Disorders. Journal of Autism and Developmental Disorders 44 (7.) 2011-2018.

16. Sreckovic M. A., Hume K., Able H. (2017). Examining the Efficacy of Peer Network Interventions ont he Social Interactions of High School Students with Autism Spectrum Disorder. Journal of Autism and Developmental Disorders 47 (8.) 3171-3178.

17. Sterzing P. R., Shattuck P. T., Narendorf S. C., Wagner M., Cooper B. P. (2012). Bullying involvement and autism spectrum disorders: prevalence and correlates of bullying involvement among adolescents with an autism spectrum disorder. Archives of Pediatrics and Adolescent Medicine 166 (11.) 1058-1064.

18. van Roekel E., Scholte R. H., Didden R. (2010). Bullying among adolescents with autism spectrum disorders: prevalence and perception. Journal of Autism and Developmental Disorders 40 (1.) 63-73.

19. Weiss J. A., Fardella M. A. (2018) Victimization and Perpetration Experiences of Adults with Autism. Frontiers in Psychiatry (9.)

20. Zeedyk S. M., Rodriguez G., Tripton L. A., Baker B. L., Blacer J. (2014). Bullying of youth with autism spectrum disorder, intellectuel disability, or typical development: Victim and parent perspectives. Research in Autism Spectrum Disorders 8 (9.) 1173-1183. 